\title{
Study of the Production of Alkaline Keratinases in Submerged Cultures as an Alternative for Solid Waste Treatment Generated in Leather Technology
}

\author{
Ivana A. Cavello, Mariana Chesini, Roque A. Hours, and Sebastián F. Cavalitto* \\ Research and Development Center for Industrial Fermentations (CINDEFI, UNLP; CCT-La Plata, CONICET), Calle 47 y 115 (B1900ASH), \\ La Plata, Argentina
}

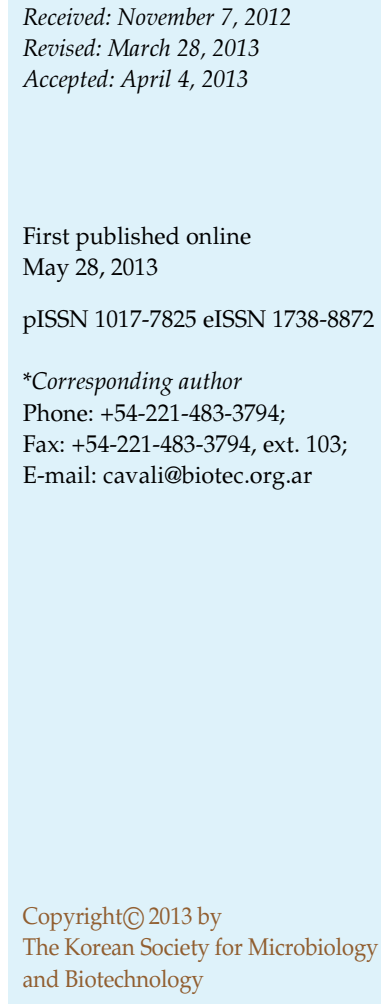

Six nonpathogenic fungal strains isolated from alkaline soils of Buenos Aires Province, Argentina (Acremonium murorum, Aspergillus sidowii, Cladosporium cladosporoides, Neurospora tetrasperma, Purpureocillium lilacinum (formerly Paecilomyces lilacinus), and Westerdikella dispersa) were tested for their ability to produce keratinolytic enzymes. Strains were grown on feather meal agar as well as in solid-state and submerged cultures, using a basal mineral medium and "hair waste" as sole sources of carbon and nitrogen. All the tested fungi grew on feather meal agar, but only three of them were capable of hydrolyzing keratin, producing clear zones. Among these strains, P. lilacinum produced the highest proteolytic and keratinolytic activities, both in solid-state and submerged fermentations. The medium composition and culture conditions for the keratinases production by P. lilacinum were optimized. Addition of glucose $(5 \mathrm{~g} / \mathrm{l})$ and yeast extract $(2.23 \mathrm{~g} / \mathrm{l})$ to the basal hair medium increased keratinases production. The optimum temperature and initial $\mathrm{pH}$ for the enzyme production were $28^{\circ} \mathrm{C}$ and 6.0 , respectively. A beneficial effect was observed when the original concentration of four metal ions, present in the basal mineral medium, was reduced up to 1:10. The maximum yield of the enzyme was $15.96 \mathrm{U}_{\mathrm{c}} / \mathrm{ml}$ in the optimal hair medium; this value was about 6.5 -fold higher than the yield in the basal hair medium. These results suggest that keratinases from P. lilacinum can be useful for biotechnological purposes such as biodegradation (or bioconversion) of hair waste, leading to a reduction of the environmental pollution caused by leather technology with the concomitant production of proteolytic enzymes and protein hydrolyzates.

Key words: Keratinases, hair waste, leather technology, Purpureocillium lilacinum

\section{Introduction}

Argentina has an economy strongly based on agriculture related industries. There are around 50 million livestock and more than 200 tanneries that process about 16 million of bovine hides per year. Although hair-saving unhairing processes reduce the organic load from beamhouse liquid effluent, a new solid residue called "hair waste" is generated, requining its appropriate disposal. The amount (as percentage of dry weight) of hair recovered from a bovine hide after this process is about 3\%. Therefore, it was estimated that a tannery, processing 25 ton of salted hides per day, produces about 2.5 ton of wet hair (70\% moisture) [19]. Nowadays, after the processing of bovine hides, the hair wastes accumulate, with its disposal being the only actual option, carrying potent polluting implications.

A typical analysis of hair waste demonstrates that the most relevant organic compound is a fibrous protein called keratin $(95 \%)$, and the remaining $5 \%$ is non-keratin proteins that can be easily extracted with buffer solutions in an aqueous medium [19]. Keratin, the main structural protein present in feather, wool, and hair and its appendages, is insoluble owing to a high degree of crosslinking of the polypeptide chains caused by extensive formation of disulfide 
bonds. This characteristic provides to this protein mechanical stability and resistance to enzyme degradation by most common proteolytic enzymes, such as trypsin, pepsin, and papain [45].

Despite their high resistance, keratins are recycled in nature by keratinolytic microorganisms. Many fungi, especially those belonging to fungi imperfecti, have keratinolytic activity, including the following genera: Chrysosporium, Aspergillus, Alternaria, Cladosporium, Fusarium, Geomyces, Paecilomyces, Scopulariopsis, Penicillium, and Doratomyces [16, $22,34,47]$. The enzymes involved in keratin degradation are called keratinases; they act as proteases but differ from the non-keratinolytic ones for their ability to degrade insoluble keratin [14].

Understandably, hair waste locks up a great deal of potentially useful proteinaceous material that could be beneficially harnessed for different purposes. Biotransformation of this waste implies considering it as raw material instead of the present idea of disposability. Thus, the hair would be the substrate onto which a microorganism (in our case, a fungus) would act (and grow), giving rise to a partially degraded organic material with high nitrogen content. This new biomaterial could show different potential uses, such as a highly digestible protein source for animal feeding, a raw material in the fertilizing or chemical industry, or a new type of hair peptone for microbial culture medium preparation.

The aim of this work was to select the most suitable microorganism with keratinolytic activity between 6 locally isolated fungal strains. The ability to grow and metabolize hair waste, in both solid-state and submerged culture conditions, was evaluated. In addition, the present work describes the effect of temperature, initial $\mathrm{pH}$, glucose concentration, salts concentrations, and different nitrogen sources in order to enhance keratinases production by the fungus selected. In order to identify the type of proteases produced, some biochemical properties of the extracellular $P$. lilacinum keratinases were determined.

\section{Materials and Methods}

\section{Microorganisms}

Six nonpathogenic fungal strains were used in this work. They were locally isolated from alkaline forest soils and belong to the Spegazzini Institute fungal culture collection (La Plata National University, Argentina): Acremonium murorum (Corda) Gams var. murorum LPS \# 57, Aspergillus sidowii LPS \# 931, Cladosporium cladosporoides LPS \# 953, Neurospora tetrasperma LPS \# 837, Purpureocillium lilacinum (formerly Paecillomyces lilacinus) (Thom)
Samson LPS \# 876, and Westerdikella dispersa LPS \# 834. Stock cultures of all strains were kept on potato dextrose agar slants under mineral oil at $4^{\circ} \mathrm{C}$ and subcultured periodically.

\section{Qualitative Test of Keratinolytic Activity on Feather Meal Agar Plates}

The ability to degrade keratin was tested on feather meal agar (FMA). This medium was composed of (g/l) feather meal, 15; $\mathrm{NaCl}, 0.5 ; \mathrm{K}_{2} \mathrm{HPO}_{4}, 0.3 ; \mathrm{KH}_{2} \mathrm{PO}_{4}, 0.4$, and agar, 15 (pH 7.2) [45]. The strains were punctually inoculated and incubated at $28^{\circ} \mathrm{C}$ for 15 days. The capability to degrade keratin was determined according to the presence or absence of a hydrolysis halo. Those strains presenting a hydrolysis halo were preselected for solid-state and submerged fermentations [45].

Inoculum Preparation for Solid-State and Submerged Fermentations

The strains were streaked on potato dextrose agar dishes and incubated at $28^{\circ} \mathrm{C}$ for 10 days. After this period of time, spores were harvested by flooding the agar dish with $10 \mathrm{ml}$ of $0.05 \%$ Tween 80 sterile solution and by gently stirring the surface with a sterile magnetic bar. The concentration of spore suspension was determined in a Neubauer chamber.

\section{Culture Medium}

A basal mineral medium described by Galarza et al. [19] was used for both solid-state and submerged fermentations. The composition of the mineral medium was (g/l) $\mathrm{NaH}_{2} \mathrm{PO}_{4}, 0.496$; $\mathrm{K}_{2} \mathrm{HPO}_{4}, 2.486 ; \mathrm{FeCl}_{3} \cdot 6 \mathrm{H}_{2} \mathrm{O}, 0.016 ; \mathrm{ZnCl}_{2}, 0.013 ; \mathrm{MgCl}_{2}, 0.010$, and $\mathrm{CaCl}_{2} 0.00011$ ( $\mathrm{pH} 7.0$ ). Hair waste, obtained from a local tannery, was washed extensively with tap water and dried at $60^{\circ} \mathrm{C}$ for 2 days, and kept at room temperature until used. In all cases, it was used as the sole carbon and nitrogen sources.

\section{Culture Conditions}

Solid-state fermentation (SSF) was carried out in autoclaved Petri dishes containing $3 \mathrm{~g}$ of hair waste impregnated with $10 \mathrm{ml}$ of basal mineral medium already inoculated with a spore concentration of $2 \times 10^{6}$ per $\mathrm{ml}$, and incubated at $28^{\circ} \mathrm{C}$ in a humid chamber for 28 days. Two dishes were withdrawn every 2 days for enzyme extraction. The extraction was carried out by adding $30 \mathrm{ml}$ of $0.5 \mathrm{M} \mathrm{NaCl}$ solution to each plate under stirring for $15 \mathrm{~min}$. The crude extract obtained was vacuum filtered through a $0.45 \mu \mathrm{m}$ cellulose membrane in an ice-water bath and kept at $-20^{\circ} \mathrm{C}$ until used for protein and activity determination [20].

Submerged fermentations (SF) were carried out in $500 \mathrm{ml}$ Erlenmeyer flasks containing $200 \mathrm{ml}$ of the basal mineral medium and $2 \mathrm{~g}$ of hair waste. The medium containing basal mineral medium plus hair waste will be called basal hair medium. Flasks were autoclaved at $121^{\circ} \mathrm{C}$ for $15 \mathrm{~min}$ and then inoculated with $2 \times 10^{6}$ conidia per ml. Cultures were performed in an orbital shaker at $200 \mathrm{rpm}$ and $28^{\circ} \mathrm{C}$ for 17 days, withdrawing $5 \mathrm{ml}$ of the culture 
every 2 days in order to obtain the crude enzyme preparation. Samples were centrifuged at $1,500 \times g$, for $15 \mathrm{~min}$, at $4^{\circ} \mathrm{C}$. The supernatant was used for $\mathrm{pH}$ determination and then kept at $-20^{\circ} \mathrm{C}$ until used for quantification of protein content and enzyme activities.

\section{Scaning Electron Microscopy (SEM)}

To characterize the degradation of hair waste by P. lilacinum, digested and undigested hair waste samples were freeze-dried and then coated with gold palladium. SEM was accomplished using a Jeol JSM-840 microscope at an accelerating voltage of $25 \mathrm{kV}$.

\section{Protein Determination}

Protein concentration was determined by Bradford's method [7] using bovine albumin fraction V (Sigma) as a standard.

\section{Determination of Enzyme Activities}

Proteolytic activity. Protease activity was measured as described by Liggieri et al. [32] using azocasein as the substrate, but with some modifications. A $0.1 \mathrm{ml}$ aliquot of the enzyme preparation, suitably diluted, was mixed with $0.250 \mathrm{ml}$ of $0.1 \mathrm{M}$ Tris- $\mathrm{HCl}$ buffer $(\mathrm{pH}$ 9.0) containing $1 \%(\mathrm{w} / \mathrm{v})$ of azocasein, and incubated for $30 \mathrm{~min}$ at $37^{\circ} \mathrm{C}$. The reaction was stopped by the addition of $1.0 \mathrm{ml}$ of trichloroacetic acid $(10 \%(\mathrm{w} / \mathrm{v}))$. The mixture was allowed to stand at room temperature for $15 \mathrm{~min}$ and then centrifuged at $5,000 \times g$ for $10 \mathrm{~min}$. A blank was performed with $0.1 \mathrm{ml}$ of heatinactivated enzyme. The $1 \mathrm{ml}$ of $1 \mathrm{M} \mathrm{NaOH}$ was added to $1 \mathrm{ml}$ of the supernatant and the absorbance was measured at $440 \mathrm{~nm}$. One unit of protease activity $\left(\mathrm{U}_{\mathrm{C}}\right)$ was defined as the amount of enzyme that, under the experimental conditions, causes an increase of 0.1 units in the absorbance at $440 \mathrm{~nm}$ per minute.

Keratinolytic activity. Keratinase activity was determined as described by Joshi et al. [27] using azokeratin as substrate. Substrate solution containing $30 \mathrm{mg}$ of azokeratin and $0.8 \mathrm{ml}$ of $0.1 \mathrm{M}$ Tris- $\mathrm{HCl}$ buffer ( $\mathrm{pH}$ 9.0) was stirred for $15 \mathrm{~min}$ until the azokeratin was completely suspended. An appropriate dilution of the enzyme preparation $(0.1 \mathrm{ml})$ was added and the admixture was incubated for $25 \mathrm{~min}$ at $37^{\circ} \mathrm{C}$. The reaction was stopped by the addition of $0.2 \mathrm{ml}$ of trichloroacetic acid $(10 \%(\mathrm{w} / \mathrm{v}))$ and centrifuged $(5,000 \times g, 10 \mathrm{~min})$. The absorbance of the supernatant was measured at $440 \mathrm{~nm}$. One unit of keratinolytic activity $\left(\mathrm{U}_{\mathrm{K}}\right)$ was defined as the amount of enzyme that, under the above-mentioned reaction conditions, causes an increase of 0.01 units in the absorbance at $440 \mathrm{~nm}$ per minute. Both azocasein and azokeratin were synthesized as described by Riffel et al. [42].

It is worth mentioning that, in the study of the optimization of medium component as well as in the biochemical characterization of crude enzymes, enzyme activity determinations were carried out as proteolytic activity, since keratinolytic (azokeratin) and proteolytic (azocasein) activities are linearly related, as was reported by Hossain et al. [24] and Correa et al. [10], a fact that was further confirmed in this paper.

\section{Optimization of the Medium Components for Keratinase Production}

Effect of metal ions present in the basal mineral medium. Several experiments were done in order to study the effect of concentrations of four metal ions $\left(\mathrm{Ca}^{2+}, \mathrm{Fe}^{3+}, \mathrm{Zn}^{2+}\right.$, and $\left.\mathrm{Mg}^{2+}\right)$ present in the basal mineral medium on keratinase production. Diluted solutions equivalent to $1: 2,1: 4,1: 10,1: 25$, and 1:50 of the original solution were tested. The initial $\mathrm{pH}$ of the medium was set at 7.0.

Effect of glucose. In order to study the effect of glucose on the production of keratinolytic enzymes, two concentrations of this sugar were tested: 5 and $10 \mathrm{~g} / 1$. The initial $\mathrm{pH}$ of the medium was set at 7.0, and the four metal ions present in the basal mineral medium were diluted up to 1:10.

Effect of nitrogen sources. The influence of various nitrogen sources on the keratinase production was studied. Yeast extract $(2.23 \mathrm{~g} / \mathrm{l})$, urea $(0.40 \mathrm{~g} / \mathrm{l}),\left(\mathrm{NH}_{4}\right)_{2} \mathrm{SO}_{4}(1.10 \mathrm{~g} / \mathrm{l})$, and $\mathrm{KNO}_{3}(1.69 \mathrm{~g} / \mathrm{l})$ were added to the basal hair medium. The initial $\mathrm{pH}$ of the medium was set at 7.0 and the four metal ions present in the basal mineral medium were diluted up to 1:10.

Effect of environmental conditions on production of keratinases. Temperature $\left(28^{\circ} \mathrm{C}\right.$ and $\left.37^{\circ} \mathrm{C}\right)$ and initial $\mathrm{pH}(6.0,7.0$, and 8.0) were evaluated using the basal hair medium.

Biochemical Characterization of the Extracellular Keratinases

All experiments referring to partial biochemical characterization of the extracellular keratinases were performed using an enzyme preparation obtained from the day of maximum enzyme production in SF.

Detection of keratinolytic activity on polyacrylamide gels (casein and keratin zymograms). Casein and keratin zymographies were performed to test the protease and keratinase activity, respectively. Zymographies were performed in conjunction with SDS-PAGE according to the method of García-Carreño et al. [21] with slight modification. SDS-PAGE was performed as described by Laemmli [30], using 5\% (w/v) stacking gel and $12 \%(\mathrm{w} / \mathrm{v})$ separating gel. In the case of SDS-PAGE, samples heated and not heated were used, and for zymography the sample was not heated prior to electrophoresis. For zymography, after electrophoresis, the gel was submerged in $100 \mathrm{mM}$ Tris-HCl buffer ( $\mathrm{pH}$ 9.0) (buffer A) containing 2.5\% Triton X-100 for $60 \mathrm{~min}$, with constant agitation in order to remove the SDS. Triton X-100 was then removed by washing the gel three times with buffer A. A portion of the gel was incubated with $1 \%(\mathrm{w} / \mathrm{v})$ casein or soluble keratin in buffer $\mathrm{A}$ at $28^{\circ} \mathrm{C}$ for 30 and $90 \mathrm{~min}$, respectively. Finally, gels were stained with Coomassie Brilliant Blue R-250 for zymography analysis. The development of clear zones on the blue background of the gels indicated the presence of protease or keratinase activity. The molecular mass markers used were phosphorylase b (97 kDa); albumin (66 kDa); ovoalbumin (45 kDa); carbonic anhydrase (30 kDa); trypsin inhibitor (20.1 kDa); and $\alpha$-lactalbumin $(14.4 \mathrm{kDa})$.

Effects of protease inhibitors and metal ions. The effects of the following inhibitors of protease activity were investigated: 
phenylmethylsulfonyl fluoride (PMSF, $1 \mathrm{mM})$, iodoacetate $(10 \mathrm{mM})$, ethylendiaminetetraacetate $(5 \mathrm{mM}), 1,10$-phenanthroline $(1 \mathrm{mM})$, and Pepstatin A (chlorambucil, $100 \mu \mathrm{g} / \mathrm{ml}$ ). The enzyme preparation was preincubated in the presence of each inhibitor for $1 \mathrm{~h}$ at room temperature $\left(20^{\circ} \mathrm{C}\right)$, and the protease activity remaining during subsequent assay was expressed as a percent of the control value with enzyme not exposed to inhibitor.

The effects of different metal ions (at a concentration of $1 \mathrm{mM}$ ) on protease activity were studied by addition of the cations $\mathrm{Ca}^{2+}$, $\mathrm{Mg}^{2+}, \mathrm{Zn}^{2+}$, and $\mathrm{Hg}^{2+}$ to the enzyme solution, followed by incubation for $1 \mathrm{~h}$ at room temperature. The protease activity remaining upon subsequent assay was expressed as a percent of the control value with enzyme not exposed to cations.

\section{Statistical Analysis}

All analyses were performed at least in triplicate. The data were expressed as means \pm standard deviations. Univariate analysis of variance (ANOVA) was employed on the data for protease activity in the study production at different $\mathrm{pH}$, temperatures, complex and inorganic nitrogen sources, and carbon supplement as well as in the biochemical characterization, and tested for their significance.

\section{Results and Discussion}

\section{Qualitative Test in Feather Meal Agar (FMA)}

In a recent screening made by the Spegazzini Institute on 69 fungal strains isolated from local alkaline soils, 32 proved to produce alkaline keratinase activity [15]. From these, 6 nonpathogenic strains were chosen because of their comparatively high keratinolytic activity (A. murorum, A. sidowii, C. cladosporoides, $N$. tetrasperma, $P$. lilacinum, and $W$. dispersa) and were tested for growth and feather meal

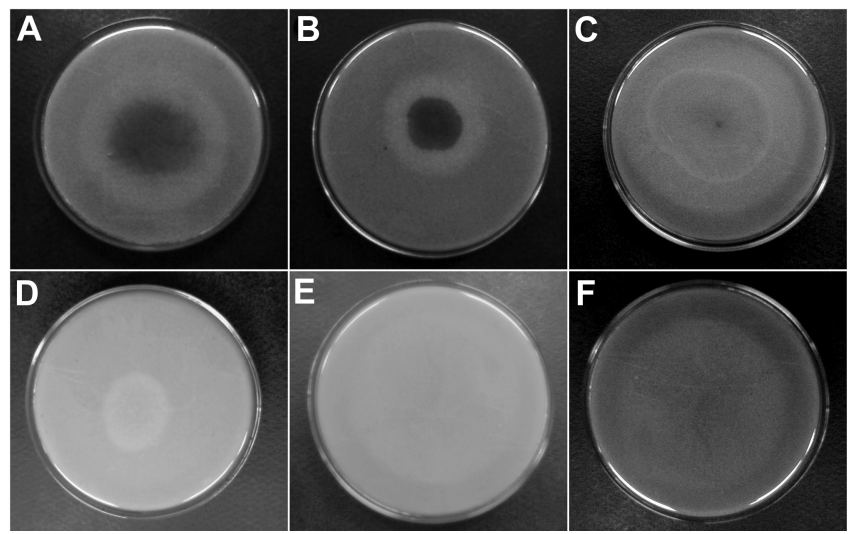

Fig. 1. Qualitative test in feather meal agar plates.

(A) A. murorum, (B) C. cladosporoides, (C) P. lilacinum, (D) A. sidowii, (E) N. tetrasperma, and (F) Westerdikella dispersa. A, B, and C: positive strains with a degradation halo surrounding the colonies. degradation on FMA. All the strains tested were able to grow, but only 3 of them (A. murorum, C. cladosporoides, and $P$. lilacinum) produced a hydrolysis halo around the colony after 15 days of culture, a fact ascribed to the production of extracellular keratinases (Fig. 1). A similar behavior has been reported in a screening of dermatophytes, where among the 16 fungal strains tested, only Trichophyton verrucosum showed tiny fungal colonies surrounded by a wide clear zone of solubilized keratin. Wawrzkiewicz et al. [51] attributed this observation to an active secretion of keratin-decomposing enzymes to the medium. Sangali and Brandelli [46] also utilized this technique in order to screen several microorganisms for their ability to hydrolyze keratin. According to the results presented in this qualitative test, A. murorum, C. cladosporoides, and P. lilacinum were selected for further experiments.

\section{Solid State Fermentations}

Solid-state fermentations have been exploited for the production of a number of fungal enzymes owing to a number of economic advantages over conventional submerged cultures. Therefore, and according to the results of plate screening using FMA, A. murorum, C. cladosporoides, and $P$. lilacinum were tested for growth and enzyme production in SSF using hair waste as substrate. Among these strains, the highest extracellular proteases production, measured by the azocasein assay, was obtained with P. lilacinum (Fig. 2A). The fungus produced a large amount of extracellular proteases, detected after 3 days, and reached the maximum level after 10 days. The proteolytic activity remained almost constant for around 8 days, showing a constant enzyme production during that period of time. Many strains of fungi and bacteria species producing protease activity (keratinase activity) under solid-state fermentation have been described $[12,29,40]$, but just one of them used hair waste as substrate; in that case, this substrate was just used to make a screening for potential keratinolytic fungi, but neither production of the proteases nor their characterization was done [15].

\section{Submerged Fermentation}

Although a number of keratin wastes have been used for the production of keratinases, there are only a few reports of the use of bovine hair waste for this purpose using submerged fermentation [33, 38, 43, 48, 52] Therefore, it was decided to test the three fungal strains ( $A$. murorum, C. cladosporoides, and P. lilacinum) for enzyme production in SF using hair waste as substrate in order to compare the fungal behavior and the enzyme production between these 

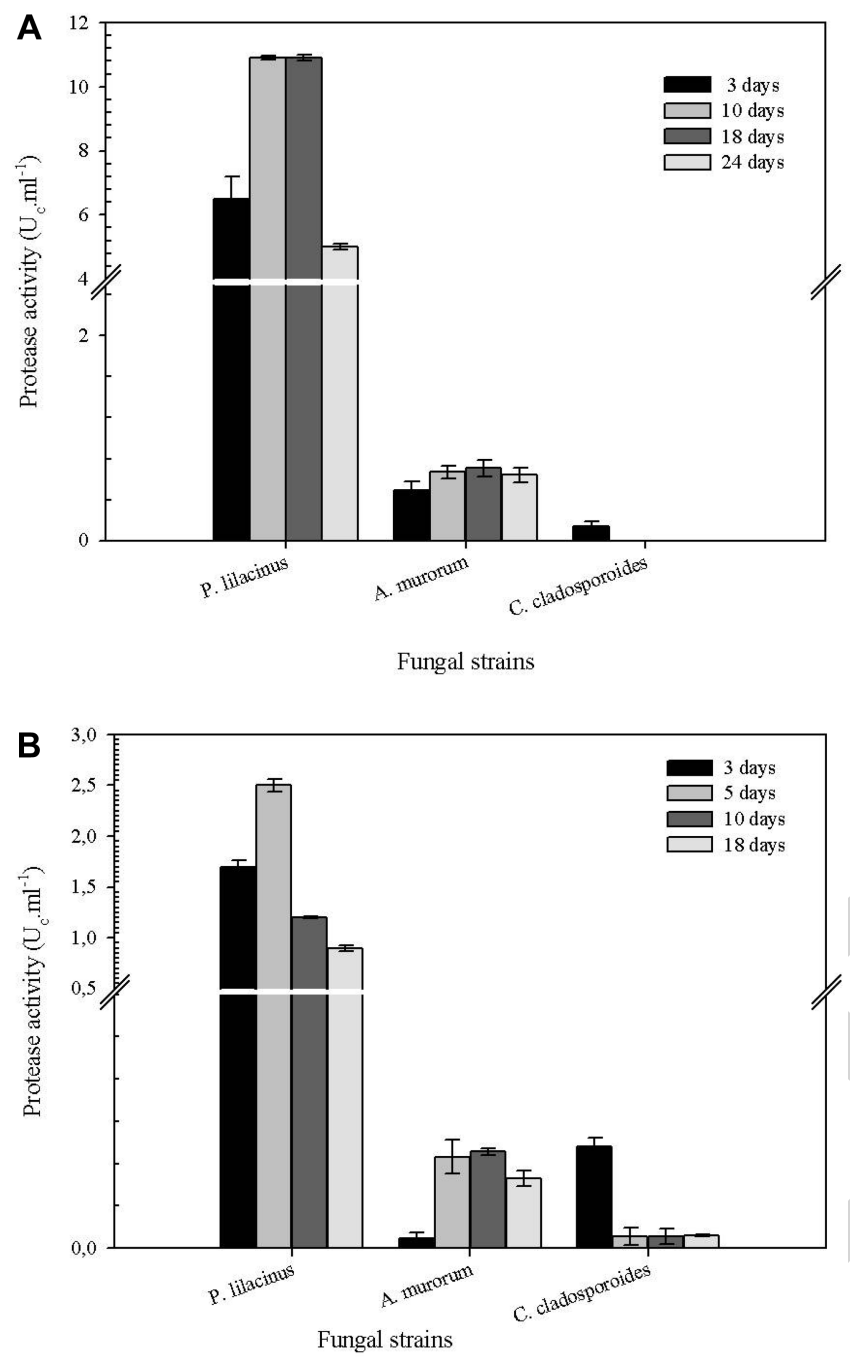

Fig. 2. Extracellular protease production by several fungal strains.

Protease activity was determined by azocasein assay after 3, 10, 18, and 24 days of incubation for solid-state cultivation (A) and after 3, 5, 10 , and 18 days of cultivation for submerged cultivation (B). Results represent the means of three experiments, and bars indicate \pm standard deviation.

two culture conditions (SSFand SF). Although the strains were able to grow, $P$. lilacinum reached the maximum production of enzyme activity after 5 days (Fig. 2B). During the whole fermentation, the $\mathrm{pH}$ of the medium increased because of the ammonia produced by the deamination of peptides and aminoacids derived from keratin solubilization [41].

On the other hand, soluble protein concentration showed a similar behavior to that of the proteolytic activity, except for the fact that the maximum peak was reached a few days later (Fig. 3). Since keratin is used as the medium component, keratinase production is accompanied by a subsequent

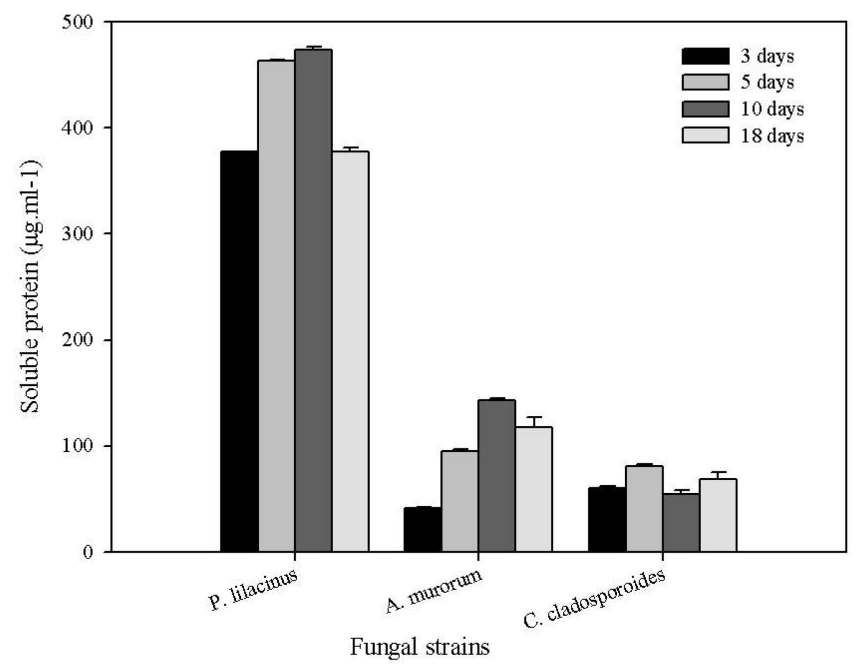

Fig. 3. Soluble protein production $(\mu \mathrm{g} / \mathrm{ml})$ by P. lilacinum after $3,5,10$, and 18 days of submerged cultivation.

Results represent the means of three experiments, and bars indicate \pm standard deviation.

degradation of keratin substrate, leading to an increase in soluble protein concentration. The increment of soluble protein has been reported as a measure for keratin degradation [5]. The decrease of soluble protein may be due to an increment of the proteolysis degree, thus releasing peptides that were not detected by Bradford's reagent.

Comparison of agar plate screening (FMA) with SSF and SF showed that the results of enzyme activity obtained were not parallel. This might be attributed to the use of different keratins sources with singular structures. Feather meal is mainly composed of a highly denatured hard keratin ( $\beta$-keratin) and could be hydrolyzed more easily than hair waste ( $\alpha$-keratin) [8]. Therefore, it can be proposed that the semi-quantitative test in FMA gives a preliminary idea of the keratinolytic capacity of a microorganism, and this property must or should be confirmed by quantitative assessment of the enzymatic production from SSF or SF using hair waste.

Accordingly to the results presented up to this point, $P$. lilacinum was selected for further studies of the optimization of the extracellular protease production.

The extent of degradation of hair waste by P. lilacinum was confirmed by SEM. Figs. 4A and 4B show SEM images of uninoculated hair fibers after a hair-saving unhairing process using sodium sulfite/lime as unhairing agent, and hairs fibers after 5 days of SF, respectively. A considerable degradation and disorganization of the fiber due to the fungal attack during SF was observed and also fungus 


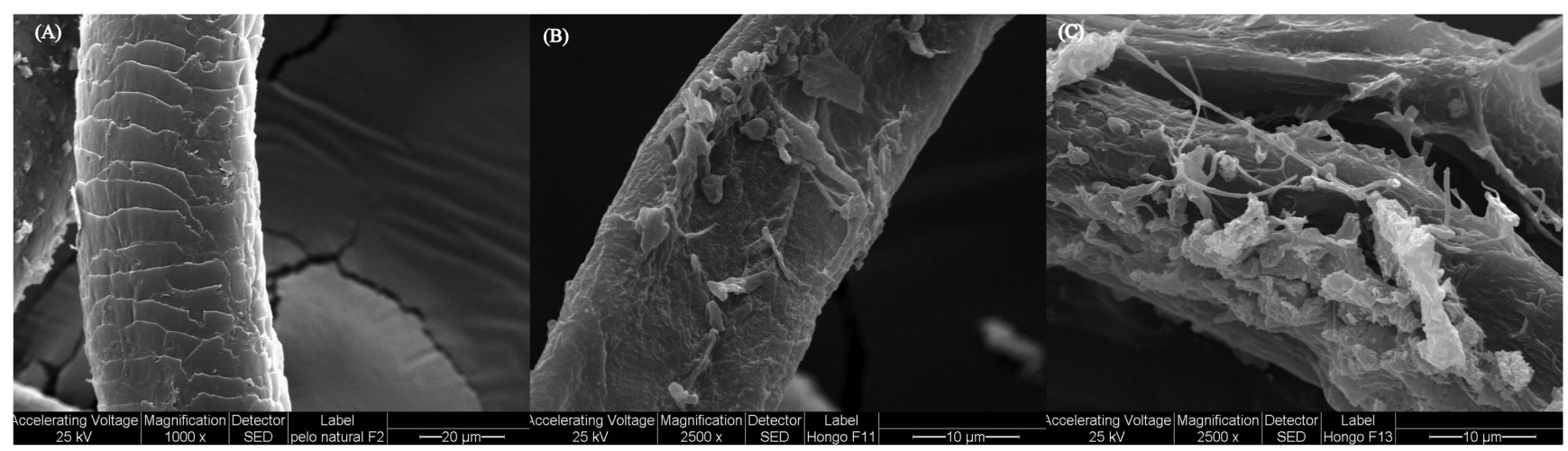

Fig. 4. Scanning electron micrographs of hair waste degradation by P. lilacinum.

(A) Uninoculated hair fibers after a hair-saving unhairing process using sodium sulfite/lime as the unhairing agent; (B) degradation of hair fibers by the fungus after 5 days; (C) colonization of P. lilacinum on hair surface.

aggregates with an extracellular matrix adhered to the degraded surfaces (Fig. 4C).
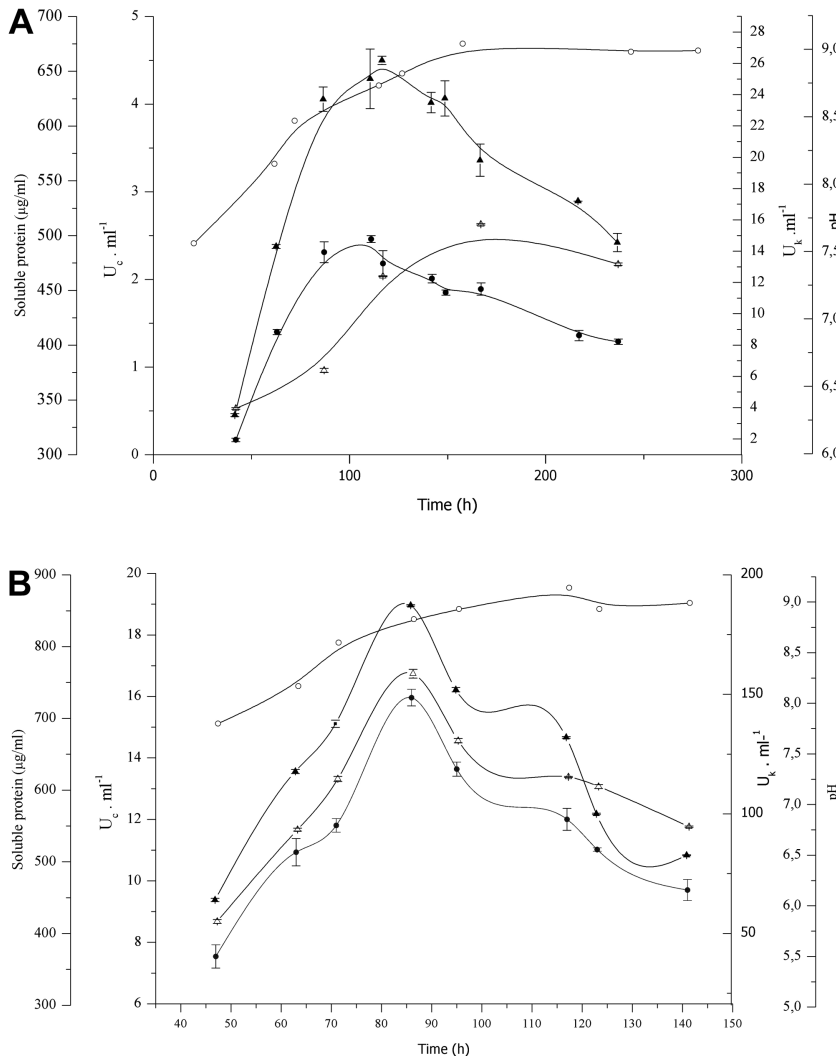

Fig. 5. Time course of keratinolytic ( $\mathbf{\Delta})$, proteolytic soluble protein $(\triangle)$ production and $\mathrm{pH}(\bigcirc)$ of $P$. lilacinum in a basal hair medium (A) and in an optimal hair medium (B). Error bars $( \pm \mathrm{SD})$ are shown when larger than the symbol.
Culture Conditions for Keratinolytic Enzyme Production

The determination of optimal growth conditions yielding the highest keratinases production was achieved by analyzing the influence of several factors. Fig. 5A shows the time courses of keratinolytic, proteolytic, and soluble protein production of P. lilacinum in the basal hair medium. Maximun protease and keratinase enzyme production of $2.46 \mathrm{U}_{\mathrm{c}} / \mathrm{ml}$ and $25 \mathrm{U}_{\mathrm{k}} / \mathrm{ml}$, respectively, was achieved at around $111-117 \mathrm{~h}$ of incubation. It can be seen in Fig. $5 \mathrm{~A}$ that both activities increased together, keeping a constant keratinolytic:caseinolytic (K:C) activity radio of $11.32 \pm 1.06$. This fact confirms the previous assumption concerning the utilization of the proteolytic activity as a direct estimation of keratinolytic activity. As was mentioned before, it was observed that the production of soluble protein had the same tendency as the production of keratinolytic enzyme. The extracellular $\mathrm{pH}$ of the medium increased constantly during the cultivation.

Temperature is an important environmental factor affecting the growth and production of metabolites by microorganisms [6]. The optimum temperature for the production of keratinolytic protease by $P$. lilacinum was $28^{\circ} \mathrm{C}$. At $37^{\circ} \mathrm{C}$, both the growth and protease activity of $P$. lilacinum were very poor (Table 1). This temperature optima for maximum enzyme production is almost similar to those reported for Vibrio sp. kr2 [45], Lysobacter sp. [2], Streptomyces sp. [12], and Penicillium sp. [13], which showed an optimum temperature for keratinases production ranging from $20^{\circ} \mathrm{C}$ to $30^{\circ} \mathrm{C}$, whereas Trichophyton sp. and Aspergillus nidulans have optimum temperatures near $40^{\circ} \mathrm{C}[3,44]$.

In order to study the effect of reducing the concentration of metal ions present in the basal mineral medium, several submerged cultures were carried out using diluted concentrations 
Table 1. Effects of temperature $\left({ }^{\circ} \mathrm{C}\right)$ and initial $\mathrm{pH}$ of the medium on keratinases production by P.lilacinum after $115 \mathrm{~h}$ of incubation.

\begin{tabular}{cc}
\hline & Protease activity $\left(\mathrm{U}_{\mathrm{c}} / \mathrm{ml}\right)$ \\
\hline $\mathrm{T}\left({ }^{\circ} \mathrm{C}\right)$ & \\
28 & $2.46 \pm 0.04$ \\
37 & $0.31 \pm 0.05$ \\
Initial $\mathrm{pH}$ & \\
6 & $4.23 \pm 0.30$ \\
7 & $2.46 \pm 0.04$ \\
8 & $2.16 \pm 0.04$ \\
\hline
\end{tabular}

Values are the average of three independent experiments \pm standard deviations.

of four metal ions present in the basal mineral medium $\left(\mathrm{Ca}^{2+}, \mathrm{Fe}^{3+}, \mathrm{Zn}^{2+}\right.$, and $\left.\mathrm{Mg}^{2+}\right)$. It is clear from the results presented in Table 2 that the enzyme production was considerably enhanced when the concentration of these four elements was reduced to 1:10. Jeong et al. [26] studied the influence of different inorganic salts on keratinases production, demonstrating that maximal production was found in a medium containing metal ions like $\mathrm{Ca}^{2+}$ and $\mathrm{Mg}^{2+}$. Studies concerning protopectinase production by Geotrichum klebahnii [17] showed that a reduction of the concentration of trace elements up to 1:85 considerably enhanced the enzyme production.

Carbohydrates, including glucose, are known as a common catabolic repressor in the production of a number of keratinases. In B. licheniformis PWD-1, glucose totally suppressed the keratinase secretion; in the case of $B$. sp MIR-99, besides glucose, glycerol and sucrose also suppress the enzyme secretion, and in the case of Paracoccus sp. WJ98 , none of the sugars tested were effective in keratinase production $[31,39,50]$. Keeping in mind this information, it was decided to test just glucose as a co-carbon source, at two different concentrations ( 5 and $10 \mathrm{~g} / \mathrm{l}$ ). The addition of this carbohydrate significantly improved the production of

Table 2. Influence of various dilutions of the metal ions present in the mineral medium on enzyme production.

\begin{tabular}{cc}
\hline Dilution of metal ions & Protease activity $\left(\mathrm{U}_{\mathrm{c}} / \mathrm{ml}\right)$ \\
\hline $1: 1$ & $2.46 \pm 0.04$ \\
$1: 2$ & $2.56 \pm 0.10$ \\
$1: 4$ & $2.71 \pm 0.17$ \\
$1: 10$ & $3.10 \pm 0.07$ \\
$1: 25$ & $2.10 \pm 0.12$ \\
$1: 50$ & $2.02 \pm 0.13$ \\
\hline
\end{tabular}

Values are the average of three independent experiments \pm standard deviations.
Table 3. Influence of glucose concentration and of co-nitrogen sources on keratinolytic enzyme production by P. lilacinum in basal hair medium.

\begin{tabular}{cc}
\hline & Protease activity $\left(\mathrm{U}_{\mathrm{c}} / \mathrm{ml}\right)$ \\
\hline Glucose & $3.10 \pm 0.07$ \\
None & $10.46 \pm 0.51$ \\
$5 \mathrm{~g} / 1$ & $10.68 \pm 0.61$ \\
$10 \mathrm{~g} / 1$ & \\
Co-nitrogen sources & $10.22 \pm 0.30$ \\
None & $15.96 \pm 0.56$ \\
Yeast extract & $2.09 \pm 0.39$ \\
Urea & $11.58 \pm 0.22$ \\
$\left(\mathrm{NH}_{4}\right)_{2} \mathrm{SO}_{4}$ & $3.57 \pm 0.60$ \\
$\mathrm{KNO}_{3}$ & \\
\hline
\end{tabular}

Values are the average of three independent experiments \pm standard deviations.

keratinase $\left(10.46 \mathrm{U}_{\mathrm{c}} / \mathrm{ml}\right)$, and as can be seen in Table 3, the increase of the concentration of glucose slightly improved the production. Similar results were reported by Jeong $\mathrm{et} \mathrm{al}$. [26], where an increase in glucose concentration from $0 \%$ to $0.1 \%$ increased the production of keratinase, but further increases with glucose up to $0.5 \%$ inhibited its production.

In order to investigate the influence of co-nitrogen sources on the keratinolytic enzyme production, $17 \mathrm{mM}$ of nitrogen of each co-nitrogen source was added to the medium containing $5 \mathrm{~g} / 1$ of glucose. Table 3 shows that the addition of yeast extract and $\left(\mathrm{NH}_{4}\right)_{2} \mathrm{SO}_{4}$ increased keratinase production 1.56-fold and 1.13-fold, respectively. However, the addition of other co-nitrogen sources, such as urea or $\mathrm{KNO}_{3}$, repressed keratinase production. It is worth to mention that the combination of yeast extract and glucose supplemented to the basal hair waste medium showed a positive cumulative influence $\left(\mathrm{U}_{\mathrm{c}} / \mathrm{ml} \sim 16\right)$ on enzyme production by this organism. Similar results were reported by Hossain et al. [24], where a combination of $\mathrm{NH}_{4} \mathrm{Cl}(0.1 \%(\mathrm{w} / \mathrm{v}))$ and molasses $(1 \%(\mathrm{w} / \mathrm{v}))$ showed a positive influence on keratinase production by $B$. licheniformis MZK-3.

Finally, the effects of the medium's initial $\mathrm{pH}$ on keratinase production were investigated in a $\mathrm{pH}$ range of 6.0-8.0. P. lilacinum was able to grow and produce proteases in the range studied, and the optimum $\mathrm{pH}$ for the production was 6.0, where the enzyme production was increased 2fold relative to the basal mineral medium $\left(4.23 \mathrm{U}_{\mathrm{c}} / \mathrm{ml}\right)$ (Table 1). This result was similar to Pseudomonas sp. KP-364 $(\mathrm{pH} 6.5)$ and Fervidobacterium pennavorans $(\mathrm{pH} 6.3)[9,18]$, but not with those reported for the production of keratinase from Paracoccus sp. WJ-98 (pH 7.5 [31]) or for the production 
of a serine protease from B. licheniformis MZK-3 ( $\mathrm{pH} 8.0$ [24]).

As result of this study, an optimal condition for the enzyme production was established. The optimal hair medium contained $0.5 \%(\mathrm{w} / \mathrm{v})$ glucose, $0.22 \%(\mathrm{w} / \mathrm{v})$ yeast extract, a dilution of 1:10 of the original solution of metal ions, and $1 \%(\mathrm{w} / \mathrm{v})$ of hair waste $\left(\mathrm{pH} 6.0\right.$ and $\left.28^{\circ} \mathrm{C}\right)$, respectively. Fig. 5B shows the time course of keratinolytic enzyme production of $P$. lilacinum in the optimal hair medium. The level of keratinolytic enzyme produced by $P$. lilacinum increased considerably (6.5-fold) and reached a maximum $\left(15.96 \mathrm{U}_{\mathrm{c}} / \mathrm{ml}\right)$ at $86 \mathrm{~h}$, and then decreased slightly.

\section{Biochemical Characterization of the Extracellular Keratinases}

Detection of keratinolytic activity on polyacrylamide gels (casein and keratin zymograms). In this study, $P$. lilacinum LPS \#876 was found to produce at least two proteases, but just one of them has keratinolytic activity as revealed by the casein and keratin zymograms (Fig. 6). These results are in line with those reported by Huang et al. [25], where just one protease was produced by B. pumilis with dehairing capabilities. Nevertheless, several works reported the production of more than one extracellular protease. Agrebi et al. [1] reported the production of at least seven proteases by B. pumilis A 26; Xie et al. [52] reported the presence of five proteases in the culture supernatant of Streptomyces sp. strain 16 growing on human foot skin medium; and Mazotto et al. [35] reported the production of
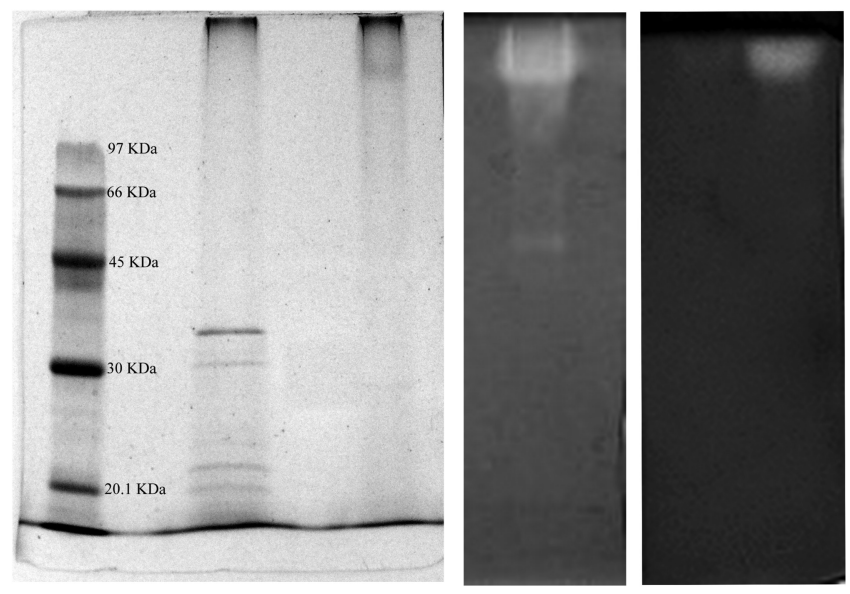

Fig. 6. SDS-PAGE and zymography analysis of the crude extract.

Lane 1: molecular marker. Lane 2: heated crude extract supernatant. Lane 3: non-heated crude extract supernatant. Lane 4: casein zymogram, and Lane 5: keratin zymogram. seven proteases in the culture supernatant of human hair medium supplemented with yeast extract by B. subtilis AMR, from which three resulted to be keratinases accordingly to keratin zymograms. Interestingly, when the supernatant was submitted to SDS-PAGE and to the corresponding zymography, it could be seen that enzyme activities were not affected by the presence of $\beta$-mercaptoethanol or by SDS (present in SDS-PAGE solutions), and the apparent molecular mass seems to be high, but when the enzyme was heated, its apparent molecular mass resulted to be near $37 \mathrm{kDa}$. Moreover, when the supernatant was subjected to a Superdex 75 chromatography, the active fraction collected was one that corresponds to a molecular mass near to $35 \mathrm{kDa}$ (data not shown), suggesting that the presence of SDS could induce conformational changes that do not affect enzyme activity. At high temperatures, denaturation "opens" the polypeptide chain, rearranging the pattern of intra and intermolecular interactions within the protein and with the solvent [4]. Similar behavior was reported by Muga et al. [37] in relation to the interaction of SDS with $\beta$-Galactosidase.

Influence of inhibitor on enzyme activity. Proteases can be classified by their inhibition profile. The effects of several of these inhibitors, such as PMSF, EDTA, pepstatin A, etc., were investigated (Table 4). The keratinases secreted by $P$. lilacinum were slightly inhibited by EDTA, pesptatin A, iodoacetate, or 1,10-phenantroline. PMSF caused strong inhibition of the enzyme activity (93\%) suggesting that the enzymes secreted belong to the class of serine proteases. This type of inhibition was reported for proteases from

Table 4. Effects of protease inhibitors and metal ions on the enzyme activity of keratinase from $P$. lilacinum.

\begin{tabular}{ccc}
\hline \multicolumn{1}{c}{ Chemical } & Concentration & Residual activity $(\%)$ \\
\hline None & & 100 \\
Inhibitor & & \\
PMSF & $2 \mathrm{mM}$ & $7.0 \pm 0.0$ \\
Iodoacetate & $10 \mathrm{mM}$ & $95.1 \pm 4.7$ \\
EDTA & $5 \mathrm{mM}$ & $99.6 \pm 6.3$ \\
1,10-Phenantroline & $1 \mathrm{mM}$ & $100 \pm 0.2$ \\
Pepstatin A & $100 \mu \mathrm{g} / \mathrm{ml}$ & $87.5 \pm 5.5$ \\
Metal ion & & \\
$\mathrm{Mg}^{2+}$ & $1 \mathrm{mM}$ & $105.0 \pm 1.2$ \\
$\mathrm{Zn}^{2+}$ & $1 \mathrm{mM}$ & $92.8 \pm 1.4$ \\
$\mathrm{Ca}^{2+}$ & $1 \mathrm{mM}$ & $102.9 \pm 0.5$ \\
$\mathrm{Hg}^{2+}$ & $1 \mathrm{mM}$ & $6.0 \pm 0.6$ \\
\hline
\end{tabular}

All the chemicals tested were preincubated with the enzyme at room temperature $\left(25^{\circ} \mathrm{C}\right)$, for $1 \mathrm{~h}$, and then the residual enzyme activity was measured. Values are the average of three independent experiments \pm standard deviations. 
Vibrio fluvialis [49], Trichophyton vanbreuseghemii [36], and Bacillus sp. JB99 [28].

Influence of metal ions on enzyme activity. As can be seen in Table 4 , in the presence of $\mathrm{Ca}^{2+}$ and $\mathrm{Mg}^{2+}$, a moderate increase of enzyme activity was observed, but in presence of $\mathrm{Zn}^{2+}$, a slight inhibition of the activity was observed. It has been reported that this metal ion has an inhibitory effect on alkaline proteases [23]. $\mathrm{Hg}^{2+}$ strongly inhibited the proteolytic activity (94\% of inhibition); this metal ion is recognized as an oxidant agent of thiol groups, and the enzyme inhibition by this ion suggests the presence of an important $\mathrm{SH}$ group (such as free cysteine) at or near the active site [11].

Through the results obtained in this work, it was possible to determine that $P$. lilacinum strain, isolated from alkaline soils from Buenos Aires Province, produced extracellular keratinolytic activity when cultivated with hair waste as a sole sources of carbon and nitrogen both in SSF and SF. The strain presents potential uses in biotechnological processes involved in the degradation of keratinous wastes from several industries, such as that of leather, contributing to the reduction in disposal problems. At the same time, it produces compounds resulting from keratin hydrolysis that can be used for the production of biodegradable films, glue and protein hydrolysates, balanced food, and fertilizers, etc. In addition, the keratinolytic enzymes involved in this biotransformation could be considered as a not less important product. After recovery, and even as crude extracts, they could find application in the food and leather industries as well as in the manufacture of textiles, cosmetics, etc. On the other hand, the optimal medium composition improved the keratinases production by about 6.5 -fold. The conditions could be applied for a large-scale fermentation system.

\section{Acknowledgments}

This research work was supported by grants from CONICET (Argentina National Council of Science and Technology, PIP 112-200801-01422) and UNLP (National University of La Plata, 11/X522).

\section{References}

1. Agrebi R, Haddar A, Hajji M, Frikha F, Manni L, Jellouli K. 2009. Fibrinolytic enzymes from a newly isolated marine bacterium Bacillus subtilis A26: Characterization and statistical media optimization. Can. J. Microbiol. 55: 1049-1061.

2. Allpress JD, Mountain G, Gowland PC. 2002. Production, purification and characterization of an extracellular keratinase from Lysobacter NCIMB 9407. Lett. Appl. Microbiol. 34: 337342.
3. Anbu P, Gopinath SCB, Hilda A, Lakshmipriya T, Annadurai G. 2005. Extracellular keratinase from Trychophyton sp. HA-2 isolated from leather dumping soil. Enzyme Microb. Technol. 36: 639-647.

4. Arrondo JL, Young NM, Mantsch HH. 1988. The solution structure of concanavalin A probed by FT-IR spectroscopy. Biochim. Biophys. Acta 952: 261-268.

5. Bálint B, Bagi Z, Tóth A, Rákhely G, Perei K, Kovács K. 2005. Utilization of keratin-containing biowaste to produce biohydrogen. Appl. Microbiol. Biotechnol. 69: 404-410.

6. Banerjee R, Bhattacharya BC. 1992. Extracellular alkaline protease of newly isolated Rhizopus oryzae. Biotechnol. Lett. 14: 301-304.

7. Bradford MM. 1976. A rapid and sensitive method for the quantitation of microgram quantities of protein utilizing the principle of protein-dye binding. Anal. Biochem. 72: 248-254.

8. Brandelli A. 2005. Hydrolysis of native proteins by a keratinolytic protease of Chryseobacterium sp. Ann. Microbiol. 55: 47-50.

9. Chon D, Kwon T. 2001. Isolation of keratinolytic protease producing microorganism and its cultivation condition. San'oeb Misaengmul Haghoeji 29: 134-141.

10. Correa AP, Daroit DJ, Brandelli A. 2010. Characterization of a keratinase produced by Bacillus sp. P7 isolated from an Amazonian environment. Int. Biodeter. Biodegrad. 64: 1-6.

11. Daroit DJ, Simonetti A, Hertz PF, Brandelli A. 2008. Purification and characterization of an extracellular betaglucosidase from Monascus purpureus. J. Microbiol. Biotechnol. 18: $933-941$.

12. De Azaredo LAI, De Lima MB, Coelho RRR, Freire DM. 2006. Thermophilic protease production by Streptomyces sp. 594 in submerged and solid-state fermentations using feather meal. J. Appl. Microbiol. 100: 641-647.

13. El-Gendy MMA. 2010. Keratinase production by endophytic Penicillium spp. Morsy1 under solid-state fermentation using rice straw. Appl. Biochem. Biotechnol. 162: 780-794.

14. El-Refai HA, AbdelNaby MA, Gaballa A, El-Araby MH, Abdel Fattah AF. 2005. Improvement of the newly isolated Bacillus pumilus FH9 keratinolytic activity. Process Biochem. 40: 2325-2332.

15. Elíades L, Cabello M, Voget CE, Galarza B, Saparrat M. 2010. Screening for alkaline keratinolytic activity in fungi isolated from soils of the biosphere reserve "Parque Costero del Sur" (Argentina). World J. Microbiol. Biotechnol. 26: 2105-2111.

16. Farag AM, Hassan MA. 2004. Purification, characterization and immobilization of a keratinase from Aspergillus oryzae. Enzyme Microb. Technol. 34: 85-93.

17. Ferreyra OA, Cavalitto SF, Hours RA, Ertola RJ. 2002. Influence of trace elements on enzyme production: Protopectinase expression by a Geotrichum klebahnii strain. Enzyme Microb. Technol. 31: 498-504.

18. Friedrich AB, Antranikian G. 1996. Keratin degradation by Fervidobacterium pennovorans, a novel thermophilic anaerobic 
species of the order Thermotogales. Appl. Environ. Microbiol. 62: 2875-2882.

19. Galarza B, Goya L, Cantera C, Garro ML, Reinoso HM, Lopez LMI. 2004. Fungal biotransformation of bovine hair part I: Isolation of fungus with keratinolytic activity. J. Soc. Leather Technol. Chem. 88: 93-98.

20. Galarza BC, Goya L, Garro ML, Mercerat J, Hours RA, Cantera CS. 2005. Fungal biotransformation of bovine hair part II: Biomass and proteases produced as a function of incubation time. Assessment of hair waste digestion. J. Soc. Leather Technol. Chem. 90: 169-172.

21. García-Carreño FL, Dimes LE, Haard NF. 1993. Substrategel electrophoresis for composition and molecular weight of proteinases or proteinaceous proteinase inhibitors. Anal. Biochem. 214: 65-69.

22. Gradišar H, Kern S, Friedrich J. 2000. Keratinase of Doratomyces microsporus. Appl. Microbiol. Biotechnol. 53: 196200.

23. Gupta R, K Beg, P Lorenz. 2002. Bacterial alkaline proteases: Molecular approaches and industrial applications. Appl. Microbiol. Biotechnol. 59: 15-32.

24. Hossain MS, Azad AK, Abu Sayem SM, Mostafa G, Mozammel Hoq Md. 2007. Production and partial characterization of feather-degrading keratinolytic serine protease from Bacillus licheniformis MZK-3. J. Biol. Sci. 7: 599-606.

25. Huang Q, Peng Y, Li X, Wang H, Zhang Y. 2003. Purification and characterization of an extracellular alkaline serine protease with dehairing function from Bacillus pumilus. Curr. Microbiol. 46: 169-173.

26. Jeong J, Lee O, Jeon Y, Kim J, Lee N. 2010. Production of keratinolytic enzyme by a newly isolated feather-degrading Stenotrophomonas maltophilia that produces plant growthpromoting activity. Process Biochem. 45: 1738-1745.

27. Joshi SG, Tejashwini MM, Revati N, Sridevi R, Roma D. 2007. Isolation, identification and characterization of a feather degrading bacterium. Int. J. Poultry Sci. 6: 689-693.

28. Kainoor P, Naik GR. 2010. Production and characterization of feather degrading keratinase from Bacillus sp. JB 99. Indian J. Biotechnol. 9: 384-390.

29. Kumar R, Balaji S, Uma TS, Mandal AB, Sehgal PK. 2010. Optimization of influential parameters for extracellular keratinase production by Bacillus subtilis (MTCC9102) in solid state fermentation using horn meal - a biowaste management. Appl. Biochem. Biotechnol. 160: 30-39.

30. Laemmli UK. 1970. Cleavage of structural proteins during assembly of head of bacteriophage T4. Nature 227: 680-685.

31. Lee Y, Kim J, Kim H, Lee J. 2004. Production and characterization of keratinase from Paracoccus sp. WJ-98. Biotechnol. Bioproc. E 9: 17-22.

32. Liggieri C, Arribére MC, Trejo S, Canals F, Avilés F, Priolo N. 2004. Purification and biochemical characterization of asclepain c I from the latex of Asclepias curassavica L. Protein J. 23: 403-411.
33. Macedo AJ, Beys da Silva WO, Gava R, Driemeier D, Pêgas Henriques JA, Termignoni C. 2005. Novel keratinase from Bacillus subtilis S14 exhibiting remarkable dehairing capabilities. Appl. Environ. Microbiol. 71: 594-596.

34. Marcondes NR, Taira CL, Vandresen DC, Svidzinski TIE, Kadowaki MK, Peralta RM. 2008. New feather-degrading filamentous fungi. Microbial Ecol. 56: 13-17.

35. Mazotto AM, Lage Cedrola SM, Lins U, Rosado AS, Silva KT, Chaves JQ, et al. 2010. Keratinolytic activity of Bacillus subtilis AMR using human hair. Lett. Appl. Microbiol. 50: 8996.

36. Moallaei H, Zaini F, Larcher G, Beucher B, Bouchara JP. 2006. Partial purification and characterization of a $37 \mathrm{KDa}$ extracellular proteinase from Trichophyton vanbreuseghemii. Mycopathologia 161: 369-375.

37. Muga A, Arrondo JL, Bellon T, Sancho J, Bernabeu C. 1993. Structural and functional studies on the interaction of sodium dodecyl sulfate with $\beta$-galactosidase. Arch. Biochem. Biophys. 300: 451-457.

38. Muhsin TM, Hadi RB. 2001. Degradation of keratin substrates by fungi isolated from sewage sludge. Mycopathologia 154: 185-189.

39. Patil CS, Gangawane AK, Hatti SS. 2010. Production and characterization of alkaline thermostable protease from newly isolated Bacillus sp. J. Plant Genom. 1: 9-17.

40. Rai SK, Konwarh R, Mukherjee AK. 2009. Purification, characterization and biotechnological application of an alkaline b-keratinase produced by Bacillus subtilis RM-01 in solidstate fermentation using chicken-feather as substrate. Biochem. Eng. J. 45: 218-225.

41. Riffel A, Brandelli A. 2006. Keratinolytic bacteria isolated from feather waste. Braz. J. Microbiol. 37: 395-399.

42. Riffel A, Lucas F, Heeb P, Brandelli A. 2003. Characterization of a new keratinolytic bacterium that completely degrades native feather keratin. Arch. Microbiol. 179: 258-265.

43. Riffel A, Ortolan S, Brandelli A. 2003. De-hairing activity of extracellular proteases produced by keratinolytic bacteria. $J$. Chem. Technol. Biotechnol. 78: 855-859.

44. Saber WIA, El-Metwally MM, El-Hersh MS. 2010. Keratinase production and biodegradation of some keratinous wastes by Alternaria tenuissima and Aspergillus nidulans. Res. J. Microbiol. 5: 21-35.

45. Sangali S, Brandelli A. 2000. Feather keratin hydrolysis by Vibrio sp. strain kr2. J. Appl. Microbiol. 89: 735-743.

46. Sangali S, Brandelli A. 2000. Isolation and characterization of a novel feather-degrading bacterial strain. Appl. Biochem. Biotechnol. 87: 17-24.

47. Santos RM, Firmino AA, de Sá CM, Felix CR. 1996. Keratinolytic activity of Aspergillus fumigatus Fresenius. Curr. Microbiol. 33: 364-370.

48. Singh J. 2002. Optimization of an extracellular protease of Chrysosporium keratinophilum and its potential in bioremediation of keratinic wastes. Mycopathologia 156: 151-156. 
49. Venugopal M, Saramma AV. 2006. Characterization of alkaline protease from Vibrio fluvialis strain VM 10 isolated from a mangrove sediment sample and its application as a laundry detergent additive. Process Biochem. 41: 1239-1243.

50. Wang JJ, Shih JCH. 1999. Fermentation production of keratinase from Bacillus licheniformis PWD-1 and a recombinant B. subtilis FDB-29. J. Ind. Microbiol. Biotechnol. 222: 608-616.
51. Wawrzkiewicz K, Wolski T, Lobarzewski J. 1991. Screening the keratinolytic activity of dermatophytes in vitro. Mycopathologia. 114: $1-8$.

52. Xie F, Chao Y, Yang X, Yang J, Xue Z, Luo Y, Qian S. 2009. Purification and characterization of four keratinases produced by Streptomyces sp. strain 16 in native human foot skin medium. Bioresour. Technol. 101: 344-350. 